\title{
CUERPOS, SEXUALIDAD E IDENTIDAD FEMENINA: LA POESÍA DE MARÍA SÁNCHEZ (1989), LuNA MigUEL (1990) Y ELVIRA SASTRE (1992).
}

Bodies, sexuality and female identity: the poetry of María Sánchez (1989), Luna Miguel (1990) and Elvira Sastre (1992).

\author{
ANA CÁNOVAS \\ UNIVERSITÉ BORDEAUX MONTAIGNE ananova09@gmail.com
}

RECIBIDO: 20 DE MARZO DE 2018

ACEPTADO: 12 DE JULIO DE 2018

RESUMEN: Los reclamos del feminismo se asocian a una reflexión acerca del lugar que las mujeres ocupan en las sociedades en que viven, y dejan al descubierto la necesidad de plantearse la manera en que la continua tentativa de dominio de los otros sobre su cuerpo establece una forma de violencia. En contrapartida, servirse de él en tanto que herramienta a través de la cual conducir sus reivindicaciones y exigir una igualdad que está siendo constantemente vulnerada, se dibuja como uno de los procedimientos clave para su emancipación. María Sánchez (1989), Luna Miguel (1990) y Elvira Sastre (1992) son tres conocidas escritoras actuales que conforman tres vías poéticas distintas pero paralelas de nuestro panorama literario, cuyos versos tienen mucho que decir en lo que concierne a su condición de mujeres. A través de ellos se reafirman como ciudadanas, trabajadoras, madres, hijas o amantes e intentan abrirse camino en un contexto que se revela frecuentemente hostil. Las páginas de sus poemarios indagan reiteradamente en aspectos como la sexualidad, la maternidad y la relación con sus cuerpos, construyendo un intento por ratificar su identidad a través de la escritura poética.

PALABRAS CLAVE: poesía española actual, feminismo, mujeres escritoras, cuerpo, sexualidad, identidad femenina, María Sánchez, Luna Miguel, Elvira Sastre.

ABSTRACT: The claims of the feminism are associated to a reflection about the position that women occupy in the society and reveal the need to think about the way in which the continuous attempt of domination by others on his body establishes a form of violence. However, how to use it as a tool to lead his vindications and to demand the equality that is being constantly damaged is one of the key proceedings for their emancipation. María Sánchez (1989), Luna Miguel (1990) and Elvira Sastre (1992) are three known current writers who represent three different, but parallel, poetical styles of our literary panorama. Their verses have much to say about their women's condition. Through them these authors are reaffirmed as citizens, workers, mothers, daughters or lovers and try to pave their way in a context which is frequently revealed hostile. The pages of their books inquiry reiteratedly in aspects as sexuality, maternity and the relation with their bodies, making up a try to ratify their identity across the poetical writing.

KEYWORDS: current Spanish poetry, feminism, women writers, body, sexuality, female identity, María Sánchez, Luna Miguel, Elvira Sastre.

Cánovas, Ana

"Cuerpos, sexualidad e identidad femenina:

la poesía de María Sánchez (1989), Luna Miguel (1990) y Elvira Sastre (1992)”

Kamchatka. Revista de análisis cultural 11 (Julio 2018): 351-378

DOI: 10.7203/KAM.11.12184 ISSN: 2340-1869

Monográfico LECTURAS DEL DESIERTO: NUEVAS PROPUESTAS POÉTICAS EN ESPAÑA 


\section{INTRODUCCIÓN}

Desde el movimiento sufragista que cobrara fuerza en el siglo XIX hasta el activismo propio de nuestro tiempo como el ejercido por el colectivo 'Femen'1, las reivindicaciones feministas conllevan una toma de conciencia sobre la posición de la mujer en la sociedad que resulta inseparable de una reflexión a propósito de la apropiación del cuerpo y su poder como arma de pronunciamiento crítico ${ }^{2}$.

\footnotetext{
${ }^{1}$ En su manifiesto, titulado En el principio era el cuerpo, encontramos: "En el principio era el cuerpo y la sensación que la mujer tenía de su cuerpo, la alegría de su ligereza y libertad. Entonces llegó la injusticia y era tan afilada que el cuerpo la sentía. La injusticia priva al cuerpo de su movilidad, cancela todo movimiento y lo aprisiona. Es necesario que revuelvas tu cuerpo contra la injusticia, que movilices cada una de sus células en la guerra contra el patriarcado y la humillación, y que digas al mundo: ¡Nuestro Dios es mujer! ¡Nuestra misión es protestar! ¡Nuestras armas son nuestros pechos desnudos! Así nace Femen y comienza el sextremismo” (Ackerman, 2014: 5).

2 Aunque la propuesta 'Femen', nacida en Ucrania y extendida a lo largo de muchos otros países -desde 2013 en España-, se haya convertido en una de las cabezas más visibles en este sentido por el uso explícito del cuerpo que profesan sus actos, no hay que olvidar otros importantes y expandidos ejemplos de reciente calado que también insisten en la violencia física, como el movimiento ' $\mathrm{Ni}$ una menos', surgido en Argentina y propagado por varios países del continente americano y España; o las iniciativas estadounidenses 'Me too' y 'Time's Up', originadas en el marco del acoso sexual desvelado por el mundo del cine. Si nos atenemos exclusivamente al ámbito español actual, son numerosísimas las organizaciones tanto nacionales -'Enclave feminista', por citar alguna- como locales -tal que la asociación bilbaína 'FeministAlde', cuyas integrantes se declaran en su página web "herederas del feminismo radical de los años 60 y 70"-, que convergieron en la multitudinaria concentración de índole global acaecida el pasado 8 de marzo con motivo del Día internacional de la mujer.

En efecto, las corrientes españolas activas tienen su antecedente más próximo en las exigencias requeridas por las agrupaciones conformadas durante la Transición, momento en que se crean movimientos políticos como el Partido feminista de España, impulsado por Lidia Falcón en 1975 y legalmente activo desde 1981 -actualmente integrado en el grupo Izquierda Unida-, con una preocupación incidente por la sexualidad de las mujeres; o se acogen propuestas exportadas cono el movimiento 'self-help', que reclama el conocimiento y exploración del propio cuerpo, y que pusieron en marcha colectivos como 'Self-Help' de Barcelona, 'DAIA' (Dones per l'autoconeixement i anticoncepció), o 'Pelvis' de Palma de Mallorca, introducido por Leonor Taboada.

El cuestionamiento en torno a la sexualidad llegó a abrazar un entorno muy local, a través de lo que fue una de las experiencias quizá más extendidas de la época, las vocalías y grupos de mujeres de barrios y pueblos, que implicó a las clases más populares, y que más tarde se encargaría asimismo de capitanear la batalla contra la violencia de género, estableciendo un estrecho vínculo con las disputas de nuestro tiempo. En aquel escenario se forjaron medidas concretas como la instauración de los primeros centros de planificación familiar, de manera que la intimidad de la mujer traspasó las fronteras de lo privado a las que hasta entonces había estado relegada, en consonancia con otros contextos internacionales que harían llegar textos como Our bodies, ourselves (1970), del 'Colectivo de Salud de Mujeres de Boston'. Las palabras de Eva Fernández Lamelas, que ha recogido y analizado los testimonios de muchas de sus protagonistas y su conexión posterior con los grupos surgidos del movimiento 15M, nos ponen en situación: "La sexualidad fue uno de los ejes que articuló el movimiento feminista de los años setenta. Las mujeres de los barrios populares, sin acceso a anticonceptivos ni al aborto, vivían conflictos acuciantes en relación a la imposibilidad de decidir sobre sus cuerpos o programar la maternidad. Estos debates les permitieron además empezar a conocer sus cuerpos, deseos y a integrar el derecho al placer como un derecho básico" (Fernàndez, 2015: 31-32).
} 
En el cuerpo femenino ${ }^{3}$ radica la parte más visible del ejercicio de la supremacía patriarcal, siendo un aspecto fundamental a la hora de inquirir en los orígenes de una subordinación sufrida durante siglos:

[...] la identificación de las mujeres con una concepción degradada de la realidad corporal ha sido históricamente instrumental a la consolidación del poder patriarcal y a la explotación masculina del trabajo femenino. De este modo, los análisis de la sexualidad, la procreación y la maternidad se han puesto en el centro de la teoría feminista y de la historia de las mujeres. En particular, las feministas han sacado a la luz y han denunciado las estrategias y la violencia por medio de las cuales los sistemas de explotación, centrados en los hombres, han intentado disciplinar y apropiarse del cuerpo femenino, poniendo de manifiesto que los cuerpos de las mujeres han constituido los principales objetivos lugares privilegiados - para el despliegue de las técnicas de poder y de las relaciones de poder (Federici, 2010: 27).

El tratamiento que del cuerpo de la mujer se ha hecho a lo largo de la historia supone quizá el mayor impedimento ante la urgencia de dar los pasos necesarios hacia la definitiva igualdad de

\footnotetext{
${ }^{3}$ Los conceptos 'cuerpo femenino', 'identidad femenina', y en general las distintas nociones de lo 'femenino' que se adoptan a lo largo de este trabajo, responden a un atajo que no profundiza en una problemática mucho más amplia que permita desarrollar la significación plural que dicha conjetura conlleva. El modelo sexual occidental, aunque se ha enriquecido mucho en los últimos tiempos, se ha venido fundamentando categóricamente en los dos sexos. Pero eso no supone que ignoremos aquí las identidades que escapan de esta dicotomía esencialista. La realidad social ya no corresponde al determinismo estrictamente biológico y la materialidad de los cuerpos y de los sujetos no se ciñe a la genitalidad o a los rasgos sexuales categóricos como signos inequívocos de identidad. Es incontestable que no todas las personas responden a esta bipolaridad entre dos géneros opuestos que coinciden con el sino fisiológico -que supondrían los dos polos de un abanico de combinaciones mucho más amplio-, y que la equivalencia entre sexo y género no se puede entender hoy como una adecuación unidireccional. Las disimilitudes adquieren connotaciones variables que se sitúan fuera de esa lógica binaria y entran en el terreno de unas construcciones culturales y personales en evolución que trascienden la entidad corporal. Lo que conocemos como 'feminidad' no deja de ser un artificio que engloba un extenso espectro de cuerpos. No obstante, y aunque la intención no es cercenar categorías herméticas, tampoco pretendemos abarcar en este escaso espacio una discusión compleja que nos llevaría a comparar las distintas perspectivas implicadas, razón por la cual no estableceremos diferencias conceptuales y nos limitaremos a la asunción de las premisas físicas o comportamentales que confieren una identidad asociada al género en el imaginario colectivo -ya sea a partir de su aceptación o desde su rechazo-, conscientes de que el análisis no puede reducirse a una definición excluyente de estos términos. Lo cierto es que, pese a que no se pretenda vincular la condición genérica -vista asimismo por muchos especialistas, con los que comulgamos, como una construcción- a las marcas corporales en exclusiva, en el caso concreto de estas poéticas estimamos que los parámetros de género se inscriben también en el cuerpo, como reclamo de una afirmación de lo identitario. Su representación permite materializar categorías que posibilitan un posicionamiento crítico - por mucho que la interpretación de las mismas pueda diferir-, incluso con el fin de replantear el propio género. Para un acercamiento exhaustivo al tema, son muy recomendables, aunque la lista es extensa, los estudios llevados a cabo por las investigadoras mexicanas Marta Lamas y Marcela Lagarde sobre la perspectiva de género, que han contribuido ampliamente a establecer los pilares de la antropología feminista; sin olvidar a la pensadora americana Judith Butler, y en especial su obra Cuerpos que importan. Sobre los limites materiales y discursivos del sexo (1993), donde propone una resemantización de las categorías genéricas y sexuales. Una de las ideas esclarecedoras al respecto, acuñada por Lagarde, sería la siguiente: "A partir del momento de ser nombrado, el cuerpo recibe una significación sexual que lo define como referencia normativa inmediata para la construcción en cada sujeto de su masculinidad o de su feminidad, y perdura como norma permanente en el desarrollo de su historia personal, que es siempre historia social. El género es una construcción simbólica y contiene el conjunto de atributos asignados a las personas a partir del sexo. Se trata de características biológicas, físicas, económicas, sociales, psicológicas, eróticas, jurídicas, políticas y culturales [...] el género permite comprender a cualquier sujeto social cuya construcción se apoye en la significación social de su cuerpo sexuado con la carga de deberes y prohibiciones asignadas para vivir, y en la especialización vital a través de la sexualidad" (Lagarde, 1996, 27-28).
} 
género, como consecuencia del uso polarizado que se le ha venido otorgando: la mujer ha sido tradicionalmente la procreadora cuyo cometido biológico principal radica en asegurar la continuidad de la especie, ser fértil se ha llegado a considerar como un auténtico filtro para ser válida en la sociedad, y la maternidad ha alcanzado las máximas cuotas de idealización y realización personal, como meta para ostentar una vida completa y rentablemente útil. La mujer, en mayor medida que sus homólogos varones, se ha tenido que preocupar cada vez más por su imagen para ser aceptada, y por evitar en todo lo posible que el paso del tiempo haga mella en su figura. El culto al cuerpo se ha transformado en un instrumento más de discriminación, incluso entre las propias mujeres, y hasta en un distintivo de poder, clasista, estrechamente enlazado con el avance feroz del sistema capitalista, que nos ha obligado a consumir avariciosamente para estar bellas y que ha acabado por convertirnos a nosotras mismas en productos del mercado.

En efecto, el cuerpo de la mujer se ve repetidamente vulnerado a través de las exigencias estéticas o de la necesidad de cumplir con su cometido maternal; pero también en el seno de otros debates que quebrantan de manera implacable su integridad como el rechazo del aborto ${ }^{4}$, o la llamada violencia machista, que se cobra decenas de vidas cada año en España ${ }^{5}$ y en todo el mundo. Poner fin a estas agresiones está en el punto de mira de los reclamos feministas, al ser

\footnotetext{
${ }^{4}$ En España, con el polémico proyecto de reforma de ley impulsado por Gallardón en 2012, se volvían a poner las cartas sobre la mesa para evitar lo que hubiera supuesto un retroceso de veintitantos años, centrándose principalmente los argumentos en defensa del derecho al aborto libre en la legitimidad de la mujer para ser dueña de su cuerpo y en la adquisición de la potestad para determinar a título exclusivo sus actuaciones en la materia. En este caso, la paradoja de que hayan sido en su mayoría los hombres de todos los tiempos - y entre ellos el cleroquienes consideren oportuno y necesario intervenir en tal litigio, ha suscitado gran parte de la reflexión, dando lugar a una mayor concienciación en lo que atañe al control inapropiado del cuerpo por parte del enclave masculino, así como con respecto a su ideologización, y a la necesidad de que la mujer se apodere lícitamente de la autoridad sobre sí misma. Resultan interesantes estas palabras de Rita Segato acerca del papel de distintas confesiones en el asunto: “[...] la religión hoy se prende al control fundamentalista de los cuerpos (y aquí coloco en el mismo plano el velo obligatorio en el islam y la obsesión antiabortista entre los cristianos) por razones que son de soberanía jurisdiccional, de control del rebaño y de exhibición de ese control, y no de orden teológico, moral o doctrinal" (Segato, 2016: 71).

Las mujeres polacas están encarando actualmente el mismo enfrentamiento a través de las llamadas 'protestas negras', desde que su conservador gobierno reveló la intención de implantar nuevas medidas, como eliminar el supuesto de la malformación fetal, tras haberse retractado de su total prohibición. Una muestra más de que esta antigua controversia sigue estando de rabiosa actualidad.

${ }^{5}$ Los casos, con sus impactantes cifras, se han hecho hoy más mediáticos que nunca y han pasado a ser un asunto central en la actual política y una preocupación internacional. Incluso se ha disparado la inquietud entre la población española, pasando del 1,8\% al 4,6\% en el último año, como afirma una reciente encuesta del CIS, a pesar de que esté muy lejos todavía de tener el alcance de otras cuitas como el paro $(65,8 \%)$ o la corrupción (35,1\%). Algunos de los sucesos recientes acontecidos en España, como la supuesta violación en grupo a una mujer por parte de cinco hombres conocidos como "La manada" o el asesinato de Diana Quer a manos de su agresor, ponen de relieve la existencia evidente de una cultura de la violación que llega a culpabilizar a las víctimas, cuestionando que no ejercieran resistencia física suficiente, la ropa que utilizan, su trato hacia los hombres, o que volvieran a casa solas... La lista de víctimas mortales por violencia machista alcanzó oficialmente en 2017 a cuarenta y ocho mujeres según datos del gobierno de finales de año. Hasta ahora, en España solo se contabilizaban los casos de lo que se entiende como "violencia de género", que hace referencia exclusivamente a las mujeres asesinadas en el contexto de una relación sentimental. Sin embargo, se está poniendo en marcha el llamado "Pacto de Estado", cuya entrada en vigor se prevé teóricamente a partir de este año en curso, con decisiones como la inclusión estadística de todas las víctimas a manos de un hombre y la contemplación de otros muchos supuestos que van más allá de la violencia física.
} 
epicentro clave en el alcance de la autodeterminación, pues como afirma bell hooks 6 , "si las mujeres no tenemos derecho a decidir sobre nuestros cuerpos, nos arriesgamos a ceder derechos en el resto de ámbitos de nuestras vidas" (hooks, 2017: 51).

El asunto del cuerpo se ha filtrado también en el campo de la creación literaria, donde, por otro lado, la falta de reconocimiento y presencia de las mujeres está lejos de agotarse. No es una porfía nueva la de las escritoras que han sido estimadas asiduamente con displicencia, llegando incluso a ser menospreciadas por sus compañeros generacionales, como confirma Rosalía de Castro ya desde el siglo XIX cuando relataba que "los hombres miran a las literatas peor que mirarían al diablo" (Castro, 1996: 494) ${ }^{7}$. Se corresponde con una carencia de visibilidad que va desde mujeres que han tenido que adoptar un pseudónimo masculino para publicar, pasando por el ejemplo de autoras silenciadas como las de la llamada Generación del 27, hasta la necesidad de crear el "Día de las escritoras" en $2016^{8}$.

Por suerte, son numerosísimas las iniciativas surgidas en los últimos años para paliar la desigualdad en la esfera artística ${ }^{9}$. En el caso concreto de la poesía, donde quizá pueda resultar aún más difícil abrirse camino respecto a otros géneros, destaca la propuesta de la asociación 'Genialogías', que realiza encuentros periódicos entre poetas mujeres y lleva a cabo la

\footnotetext{
${ }^{6}$ Como explica Ochy Curiel en el prólogo a la obra de hooks, la autora ha optado por escribir su nombre y apellido en minúscula, "cuestionando el canon gramatical hegemónico que señala que los nombres propios deben escribirse en mayúsculas. Para ella lo más importante son las ideas que están vertidas en sus textos, no tanto quién es ella" (hooks, 2017: 13-14).

${ }^{7}$ Un lastre que retrataba asimismo Virginia Woolf más de medio siglo después en Una babitación propia (1929), donde analizaba las dificultades de las mujeres para ejercer la escritura desde épocas precedentes y en la suya propia, que marca el inicio de su emancipación: "Durante millones de años las mujeres han estado sentadas en casa, y ahora las paredes mismas se hallan impregnadas de esta fuerza creadora, que ha sobrecargado de tal modo la capacidad de los ladrillos y de la argamasa que forzosamente se engancha a las plumas, los pinceles, los negocios y la política. Pero este poder creador difiere mucho del poder creador del hombre. Y debe concluirse que sería una lástima terrible que le pusieran trabas o lo desperdiciaran, porque es la conquista de muchos siglos de la más dura disciplina y no hay nada que lo pueda sustituir" (Woolf, 2008: 63).

${ }^{8}$ Este artículo de La Vanguardia, con el testimonio de la escritora Laura Freixas, recoge: "[...] este día se celebra porque las escritoras casi no figuran en los premios institucionales, celebraciones oficiales, programas escolares, libros de texto... Queremos reivindicarlas como figuras de autoridad, si queremos una sociedad de iguales nos faltan referentes femeninos, también en lo literario". [...] "Desde mi primer libro sobre el tema, en el año 2000, el único avance es que ahora hay conciencia de la desigualdad". Las cifras son alarmantes en varios ámbitos: sólo el 7\% de las películas que se ruedan en España son dirigidas por mujeres, y sólo lo son el 4\% de los artistas españoles en Arco. En el mundo del libro, como cuenta Freixas, "desde hace treinta años, las mujeres son mayoría entre los lectores y los licenciados de todas las carreras de letras. Sin embargo, el porcentaje de mujeres entre los ganadores del Cervantes es del $10 \%$ y las del Nacional de narrativa suponen el 5\%, desde 1977 hasta hoy sólo lo obtuvieron Carmen Martín Gaite y Carme Riera, esta última en 1995. ¿Hace 21 años que ninguna autora se lo merece?” (Ayén y Massot, 2016).

${ }^{9}$ Ejemplos ilustrativos podrían ser 'La nave invisible', un espacio dedicado exclusivamente a escritoras de ciencia ficción, terror y fantasía; el proyecto 'Traficantes de sueños', que integra un área de trabajo específica sobre feminismo y publica numerosos ensayos críticos desde esta perspectiva y bajo libre descarga; las propuestas tuiteras 'LeoAutoras' o 'AdoptaUnaAutora', impulsadas con el fin de promover la lectura de mujeres escritoras y darles visibilidad a través de las redes; otro hashtag nacido en Twiter y lanzado por la autora británica Joanne Harris para denunciar la realidad opresora que sufren las mujeres que ejercen esta profesión, 'ThingsOnlyWomenWritersHear'; la asociación 'Clásicas y Modernas,' que lucha por la paridad en el mundo del arte y por rescatar autoras invisibilizadas; la celebración anual del festival 'Ellas crean', que reúne y rememora a artistas de disciplinas varias desde 2004, y que el año pasado formó parte del programa internacional 'He for She Arts Week' organizado por 'ONU Mujeres'; o la labor de editoriales que apuestan y dan voz a numerosas escritoras, como 'La Señora Dalloway'.
} 
recuperación de escritoras insuficientemente presentes para enmendar el déficit. En el plano editorial, despunta 'La Bella Varsovia', dirigida por Elena Medel, donde las publicaciones de mujeres son prioridad, enmienda necesaria a juzgar por otra sugerente aportación: el documental Se dice poeta, de Sofía Castañón, que pone de relieve el difícil transitar de las mujeres poetas por el mundo literario.

Resistiendo a ese confinamiento y a las condiciones poco paritarias, en el universo poético de las mujeres se tejen hilos que hilvanan una tradición de temáticas y reflexiones compartidas en torno a interrogantes que incurren directamente en un cuestionamiento de género. Si los movimientos feministas actuales beben de aquellos que nos preceden, en el campo lírico los trasvases dan cuenta de un patrimonio vivo de autoras que han tratado reiteradamente su condición sexual y su identidad femenina en su producción. Bastan solo algunos ejemplos que abarcan a precursoras como Ángela Figuera (1902-1984) y composiciones como "El grito inútil”, del poemario del mismo título (1952): “¿Qué vale una mujer? ¿Para qué sirve/ una mujer viviendo en puro grito?/ ¿Qué puede una mujer en la riada/ donde naufragan tantos superhombres [...]?” (Figuera, 1986: 171); la poeta catalana María-Mercé Marçal (1952-1998), que aborda el amor entre mujeres (La germana, l'estrangera, 1985), el embarazo, la posibilidad de aborto y el proceso que conlleva convertirse en madre, como desarrolla el poema "Maternitat" (Desglaç, 1988): "Desde el primer momento no fue moneda fácil/ tu risa. ¿Qué tentáculo/ ahogaba su estallido allá en la cuna?/ Las guerras, bien lo sé, no son alegres” (Marçal, 2004: 49) -pero también el cáncer de mama, causa de su prematura muerte, y su incidencia en el cuerpo (Raó del cos, 2000); sin olvidar el alegato de escritoras más recientes, como Aurora Luque (1962), que publicó en 2015 su Personal y político, con tintes feministas ya desde su título; o la trayectoria de la poeta gallega Miriam Reyes (1974), atravesada por una indagación recurrente en lo que concierne al placer, la exigencia de la maternidad y las preocupaciones sociales relativas a la mujer, con rúbricas como "Presiento el desastre de la maternidad" o "Eventualmente paso días enteros sangrando" 10 .

La elección de las tres autoras actuales que aquí presentamos, radica en el hecho de que constituyen una evidencia representativa de distintos estilos que confluyen en la poesía de nuestros días, siendo mujeres que ejercen una importante actividad en las redes, tienen miles de seguidoras, y publican con éxito. Sus versos prosaicos respiran femineidad, ganas de contar desde su condición de mujeres, y el cuerpo y su sociabilidad se expanden considerablemente por sus páginas. Pero, ¿qué las hace conectar con el público y con la crítica? ¿Hay elementos comunes en su poética que nos lleven a hablar de "rasgos generacionales"? ¿Existe relación entre el auge de la poesía hecha por mujeres y el poder creciente de los movimientos feministas?

\footnotetext{
10 Aunque la nómina de mujeres poetas actuales es inabarcable aquí, nos parece representativa la visión de conjunto que propone la antología (Tras)lúcidas; poesía escrita por mujeres (1980-2016), publicada en la editorial Bartleby en 2016, donde la también poeta Marta López Vilar recopila manifestaciones de 29 autoras nacidas entre 1962 y 1986.

Tampoco podemos obviar el enfoque feminista de algunos referentes extranjeros esenciales, muchos de ellos incidentes en las poéticas de estas mujeres, como Anne Sexton (1928-1974), Sylvia Plath (1932-1963) o Gioconda Belli (1948); así como el tratamiento de la enfermedad y las mellas sobre lo físico en Alejandra Pizarnik (1936-1972).
} 
El análisis de sus propuestas bajo la perspectiva de género ${ }^{11}$ y la manera en cómo éstas contribuyen a percibir el entramado femenino configura el meollo de este trabajo, que se esfuerza por señalar una disputa de lo corporal que ha salpicado poderosamente al recinto literario, donde se advierte una reapropiación igualmente necesaria. Según estas palabras de la pensadora Geneviève Fraisse, "hoy es la cuestión del cuerpo de las mujeres la que está en el corazón de los debates, que es una cuestión política. Y es todo el imaginario colectivo en torno al cuerpo de las mujeres lo que hay que cambiar. Para ello, va a hacer falta ser creativo"12 (Caldini, 2017). Ellas, desde luego, lo son. Y han venido para quedarse.

\section{María SÁNCheZ: “A mí/ QUE ME GUSTA SITUAR LAS COSAS/EN LA REGIÓN EXACTA/ DARLES UN SIGNIFICADO/ PROVEERLAS DE UNA HISTORIA" (SÁNCHEZ, 2017: 28).}

La pluma de María Sánchez (Córdoba, 1989) brinda una de las apuestas más novedosas y singulares del panorama literario actual. Su primer libro, Cuaderno de campo (La Bella Varsovia, 2017), ha sido acogido plausiblemente, llegando a ser su autora catalogada como una de las veintiuna artistas más influyentes del año 2017 (H. Riaño, 2017).

Esta veterinaria de profesión y asidua escritora, sorprende con un debut difícil de enmarcar en su contexto, con una voz agradablemente disonante y fresca en su complejidad. La cordobesa ejecuta desde sus versos un recorrido por su genealogía familiar en un intento por situarse a sí misma y reivindicar su posición a través del poema. La herencia recibida va trenzando las estrofas, marcadas por la constante fusión entre el mundo animal que tan bien conoce la autora y la propia especie humana, entre los cuales no siempre se muestran claros los límites: "soy un organismo como cualquier otro" (Sánchez, 2017: 27), llegando incluso a ser partícipes de la misma decadencia: "- las aves y este cuerpo siempre buscaron la [caída/ — hombres y animales siempre comparten la [misma página” (Sánchez, 2017: 57) ${ }^{13}$.

\footnotetext{
${ }^{11}$ Las palabras de Marcela Lagarde nos sirven para contextualizar el espíritu y la intención que promueven nuestro enfoque: "La perspectiva de género tiene como uno de sus fines contribuir a la construcción subjetiva y social de una nueva configuración a partir de la resignificación de la historia, la sociedad, la cultura y la política desde las mujeres y con las mujeres. Esta perspectiva reconoce la diversidad de géneros y la existencia de las mujeres y los hombres, como un principio esencial en la construcción de una humanidad diversa y democrática. Sin embargo, plantea que la dominación de género produce la opresión de género y ambas obstaculizan esa posibilidad. Una humanidad diversa democrática requiere que mujeres y hombres seamos diferentes de quienes hemos sido, para ser reconocidos en la diversidad y vivir en la democracia genérica [...] La creciente utilización de la perspectiva de género en la elaboración de interpretaciones, diagnóstico y políticas públicas, ha permitido, en efecto, la visibilización de las mujeres y de la problemática que las envuelve, así como lograr avances en la emancipación femenina” (Lagarde, 1996: 19).

12 “Aujourd'hui c'est la question du corps des femmes qui est au cœur des débats, qui est politique. Et c'est tout l'imaginaire collectif autour du corps des femmes qu'il faut changer. Pour cela, il va falloir être inventif". La traducción es nuestra.

$13 \mathrm{Si}$ bien no es el aspecto que nos urge poner de relieve en estas páginas, parece necesario precisar que la formulación poética de María Sánchez -así como varias producciones de Luna Miguel- se inserta asimismo en el campo de la ecocrítica y el pensamiento animalista, en el seno de los estudios y las propuestas que inciden en el análisis de los vínculos entre medioambiente y literatura. Esta tendencia responde a una voluntad de hermanar la perspectiva cultural y las preocupaciones derivadas del espacio de lo ecológico, con el fin de profundizar en el estudio de las relaciones entre el hombre y el animal y asentar los fundamentos de una reflexión capaz de contribuir a su evolución teórica y crítica.
} 
$\mathrm{Y}$ es que en este trabajo se delibera sobre el lugar que ocupa la mujer protagonista, pero también se alberga una toma de conciencia referida al valor del campo y nuestra incomprensión del mismo, que al margen de las ciudades que se imponen en nuestra geografía, se revela imprescindible pese a su creciente desprestigio y abandono, y se convierte para la autora en su "narrativa invisible, porque es de donde surge todo" (Neira, 2017).

La voz poética se esfuerza insistentemente por desmarcarse de los roles enraizados y reafirmarse en una red eminentemente masculina, aun sabiendo el riesgo que comporta "levantar la vista fuera de los límites establecidos" (Sánchez, 2017: 37). En una entrevista, la propia autora explica cómo devino la primera mujer veterinaria de su familia, asentando la tercera generación dedicada con pasión a esta dura profesión tras los precedentes de su abuelo y su padre, como recrea asimismo en una de sus composiciones: "Soy la tercera generación de hombres que vienen de la tierra y de la sangre. [...] yo con tu edad yo y tu abuelo yo y los hombres" (Sánchez, 2017: 67).

Ante la hegemonía patriarcal, el sujeto poético confiesa no tener todavía "nada/ en las manos" (Sánchez, 2017: 18), nos habla de "rebuscar con los dedos las raíces" (Sánchez, 2017: 19). María Sánchez se dispone a escarbar en las profundidades de sus orígenes para construirse a sí misma a partir de ellos, no desde la imitación, sino teniéndolos en cuenta hasta encontrar su propio lugar en la estirpe. Así, la palabra 'biografía' recorre el libro "como el fantasma que asusta/ y huye resbaladizo" (Sánchez, 2017: 35), y sirve de punto de partida para el relato de su experiencia, si bien no parece fácil hacerse hueco en este territorio de potestad masculina en el que cada sexo tiene su papel desde el principio de los tiempos: mientras ellas trabajaban la tierra, ellos se dedicaban a la caza, perpetuando "al depredador y al linaje” (Sánchez, 2017: 17), que hoy carga a sus espaldas las secuelas de ese desajustado legado, como concluye: "no os engañéis,/ la anatomía del canto/ la ejerce más el macho/ que la hembra” (Sánchez, 2017: 20).

La reivindicación es elegantemente sutil, lo que distinguimos es esencialmente indagación, intento de conocerse mediante interrogaciones tácitas, pero con convencimiento - "me toca hablar a mí" (Sánchez, 2017: 29). En este sentido, el título no puede ser más efectivo: cada poema toma la forma de una anotación que deriva de la investigación llevada a cabo durante años, de la observación que va instituyendo un planteamiento y sus hipótesis, como pasos lógicos para llegar a las conclusiones.

A través de un anhelo de lo rural, vigente desde los recuerdos de la infancia — "hay barro donde estaban las gallinas”, así empieza el poemario (Sánchez, 2017: 17)—, las imágenes faunísticas se hacen constantes. El ingrediente emocional respecto de los animales y una alta estima y deferencia hacia ellos, es patente a lo largo de todo el poemario, en muchas ocasiones para poner en tela de juicio el comportamiento humano, especie invasora que altera el orden natural del sistema y que tiene mucho que asimilar acerca del mundo que le rodea: "Los coyotes machos permanecen con la hembra durante todo el embarazo y llevan comida a las crias, hecho poco habitual en los mamiferos" (Sánchez, 2017: 33).

"De generación en generación" -como se titula uno de los poemas (Sánchez, 2017: 43)-, desde esa "bala de mi bisabuelo" que "agrieta mi costado", se deduce la omnipresencia del reino animal en el núcleo familiar dibujado, salpicado de sangre, marcado por esa "primera mancha" 
que la autora dice ser ella misma ${ }^{14}$ (Sánchez, 2017: 17, 45), dilatándose en su búsqueda, haciendo que esa simbiosis se haga cada vez más confusa, menos delimitada, y siempre desde la consciencia de la supremacía establecida por el hombre: "Ahora que no sabemos diferenciar/ la voz del mugido/ el pasto del alimento/ aquí nosotros,/ aquí tus vacas,/ abuelo" (Sánchez, 2017: 50). El 'yo' lírico busca reiteradamente el reconocimiento, la aprobación en ese mundo de hombres que la conduce a preguntarse: “¿quién recogerá todo lo que una mujer escribe?” (Sánchez, 2017: 49). Sus versos avanzan hacia la visibilización, el cuerpo femenino se inmiscuye en ellos intentando "constituir una narrativa" (Sánchez, 2017: 58), que se hace efectiva mediante la imagen repetida del pecho, un pecho que no alimenta y pierde su vínculo reproductivo, un pecho que da cobijo, que es "isla", "paraíso" y "cúmulo de leche invisible, sudor y sangre" (Sánchez, 2017: 58). María Sánchez otorga a este componente corporal una fuerza tradicionalmente asociada al trabajo varonil, lo aleja de la mirada tierna unida a la maternidad para asignarle el denuedo que también engendra para la mujer el ejercicio de este severo oficio. Se trata de desfigurar el retrato de un pecho hecho objeto por el androcentrismo, que se ha apropiado de él otorgándole significaciones, sexualizándolo, hasta el punto de que la propia voz poética lo desconoce, ignora la naturaleza genética que lo hace ser una parte del cuerpo como otra cualquiera, puramente biológica:

Yo que os enseñé con esta parte de mi cuerpo a tener hambre, soy incapaz de responder si me preguntan: señorita, diga la región exacta, concreta, única, señorita, dígame todos los nombres correctos de vasos y venas, ganglios y linfa, músculos y grasa, tipo de divisiones y de células... pero señorita, ¿cómo que no lo sabe? si estamos hablando de su propio cuerpo (Sánchez, 2017: 58).

Empezar de cero, sorteando la tradición acumulada, infiere volver a lo esencial y edificar los nuevos cimientos, emprendiendo la aprehensión de la propia anatomía, desnuda de estereotipos adquiridos pese a las sujeciones, que en este caso se interponen tanto en la profesión de veterinaria como en la tarea de escritora, trazando un cuestionamiento continuo. Es la exploración a la que asistimos en el poema "Un cuchillo corta todo lo que yo quiero hacer todo lo que yo pretendo escribir" ya desde el título: “¿podré caminar como es debido con el cuerpo recién hecho?/ ¿y recién cortado?/ Ya tengo abiertas las rodillas/ no quieren infancia" (Sánchez, 2017: 71).

La niñez es una etapa elemental plasmada en el poemario. En ella se gestan conductas y conjeturas asumidas maquinalmente por la voz poética adulta, que ahora la rechaza, que busca diluirla de modo que le permita reaccionar ante lo que se vive como un impedimento que es necesario transformar. Nacer mujer implica incontestables trabas añadidas que determinan a la protagonista cuando se apresura a renovar la estática herencia recibida: "Madre, con qué limpio estas manchas de nacimiento [...] padre no me enseñó a huir/ solo a quedarme quieta y a no hacer ruido" (Sánchez, 2017: 72).

\footnotetext{
14 Afirma la autora en la entrevista realizada por Oriette D’Angelo: "Esa mancha que se extiende y evoluciona en el libro, soy yo. La primera mancha, que así se titula la primera parte, es la primera mujer que decide seguir la tradición de su familia, que decide ser veterinaria, como su abuelo y como su padre. De pequeña, siempre quise ser chico. Aunque mi familia nunca me trató como tal, yo solo veía hombres en este mundo y quería ser como ellos, formar parte de esa ceremonia, convertirme en uno más. Pero esa mancha crece y entiende, después de los años, que no necesita ser como ellos, que ella, como mujer, tiene un camino y lucha diferente, y muchísimo por hacer y contar" (D’Angelo, 2017).
} 
En gran medida, en este poemario la autora equipara el cuerpo humano — a menudo desde un punto de vista individualista, como apunta Xaime Martínez (2017) — al animal, para intentar despojarlo de los lastres que se le han ido confiriendo y que han disipado lo más esencial de su naturaleza. De acuerdo con Oriette D'Angelo, “Sánchez habla de la corporalidad desde lo terrenal" (D'Angelo, 2017). Ser mujer, como ser animal, conlleva un sufrimiento añadido, pues ambos son seres con frecuencia castigados y relegados a un estado de subordinación pese a ser indispensables en el ciclo vital. Si la voz poética es víctima de los excesos de ese sometimiento en el seno de su labor profesional, por momentos se siente más cerca de los animales que de sus propios compañeros varones: "Ellos me hablan como a un hombre. Ellos esperan de mí lo que esperan de un hombre./ Pero yo sangro. Animal o mujer: hecha de sueño y lágrimas" (Sánchez, 2017: 69).

En esta obra, María Sánchez captura un mundo que queda muy lejos de las nuevas tecnologías que absorben nuestro transitar cotidiano, desde la reivindicación del campo, que como ella misma afirma, se convierte en una "forma de resistencia” (D’Angelo, 2017). El campo no es el lugar idílico que muchos han descrito, sino un medio marcado por el sufrimiento y el trabajo exigente en el que la mujer se abre camino. Es innegable que este libro tiene mucho de feminismo implícito, desde el cual la autora discute su emplazamiento en una sociedad androcéntrica que la golpea en sus propias carnes para averiguarse a través de la escritura poética y empezar a dominar el espacio que le corresponde, como ella misma confiesa:

Siempre tuve claro que quería que mi primer libro fuera una manera de presentarme, de declarar mis intenciones. [...] Soy feminista desde que me di cuenta que me movía y que trabajaba en un mundo de hombres. Creo que tiene un peso fuerte en ambas vertientes. Nosotras necesitamos contar nuestra historia, que nuestra voz se oiga, que no se nos ignore, ni se nos aparte a un lado por ser mujer (D’Angelo, 2017).

Aunque el poemario contenga un fuerte componente autobiográfico, no hay duda de que la experiencia es extensible a otras muchas mujeres con las que la autora ha tenido contacto en su entorno inmediato, como relata la propia poeta cordobesa en la entrevista con D'Angelo, en el contexto de su profesión y sus visitas a zonas de campo - pero también a las escritoras que buscan hacerse un hueco al amparo de la literatura. María Sánchez no solo sondea sus orígenes familiares, sino los de una sociedad española que ha olvidado injustamente de dónde viene. Que este trabajo haya conocido a día de hoy su octava edición señala la positiva acogida de la propuesta, la necesidad de voces femeninas que griten con intensidad lo que muchos parecen deseosos de escuchar, cuyo éxito radica tanto en la vuelta al mundo rural que suponen estos versos como en su poderosa carga ideológica. Como afirma Juan Fernández Rivero sobre el poemario:

[...] no solo alcanza el hueso de otras poéticas que han reclamado el cuerpo de manera tópica o vacía, sino también la exigencia de una teleología común, tan necesaria ahora que la distancia entre los cuerpos se ha densificado a causa de los dispositivos de control biopolítico y de las lógicas de consumo y producción del capitalismo financiero (Fernández, 2017).

Esta ópera prima es además una prueba fehaciente de que la comunión de las letras y las ciencias se muestra efectiva en su ejecución, de que se puede escribir una realidad biológica, 
literalmente vital, y dotarla de un elevado carisma estilístico, que invita a dejarlo todo y comenzar un retiro desde el que regresar al principio, excavar las raíces y hacer que surjan palabras sepultadas.

\section{LUNA MigUEL: “EL FIN DEL MUNDO ES CRECER” (MigUEL, 2013: 103)}

La que se ha venido a llamar una "trilogía accidental" (Yuste, 2017) que empezara con La tumba del marinero (La Bella Varsovia, 2013) para seguir con Los estómagos (La Bella Varsovia, 2015) y terminar con el reciente El arrecife de las sirenas (La Bella Varsovia, 2017), consolida a su prolífica autora, Luna Miguel (Madrid, 1990), como una de las voces más personales y genuinas de nuestras letras y la enmarcan como "la poeta del cuerpo"15.

En efecto, el cuerpo, ya sea cruelmente corroído por la enfermedad en el primer título, en referencia al órgano vital que da origen al segundo y que está ligado a las funciones básicas de éste, o con respecto a la posibilidad del vientre femenino de generar vida en el tercer trabajo, se manifiesta como un eje vertebrador de la poética de Luna Miguel y se articula en una estrecha analogía con la vida y su reverso.

$\mathrm{Al}$ igual que sucede en el caso de María Sánchez, los tres poemarios están decididamente marcados tanto por la historia familiar como personal de la autora, lo que provoca que a lo largo de las sucesivas entregas se vaya entramando un universo lineal en torno a su trayectoria vital, traspasada por diversas experiencias, a menudo dolorosas, que la escritura se encarga de conectar. Son fracciones de una existencia que lucha con los contratiempos y desavenencias de nuestro mundo de hoy, que nos hacen partícipes de su transcurrir como si de una confesión pseudoterapéutica se tratara. $\mathrm{Y}$ es inevitable no sentirse identificado con una realidad que en alguna de sus aristas nos resulta conocida.

En el primer caso, la enfermedad es la protagonista intangible que transita por sus páginas. El cáncer, transido de muerte, que ha azotado a su familia, es el motivo cruel que se transforma en el engranaje de muchos de los poemas, si bien descubrimos asimismo de forma paralela el recorrido por la 'independencia' - como se titula una de las secciones - de la autora, la convivencia con una diabetes que la ha acompañado desde que tenía once años (Salgado, 2013), y que la llevan a concebir composiciones como este "Coma diabético", en el que corporeidad e ideología se dan la mano:

Tú me diste una boca.

Mi madre me dio este páncreas.

\footnotetext{
${ }^{15}$ En la entrevista efectuada por María Yuste, aclara la propia autora en relación a esta denominación y los motivos que la llevaron a concluir la trilogía: "Siempre me decían que yo era la poeta del cuerpo así que, llegados a ese punto, decidí reflexionar seriamente sobre qué es un cuerpo, un cuerpo femenino para mí. Si La tumba... es el pulmón enfermo y Los estómagos es, con todo lo que he explicado antes, el estómago, me di cuenta de que la siguiente fase tenía que ser la vida. Volver a esa vida que, a su vez, volverá a enfermar y volverá a ser el pulmón enfermo. Por eso tenían que ser 3 libros y no 2. La vida me había llevado a cosas oscuras, pero yo quería generar cosas luminosas y vi que esas cosas luminosas solo se podían generar desde el útero, capaz de dar vida" (Yuste, 2017).
} 
La Ciencia me dio insulina.

Dios no me dio nada

salvo miedo

en un puñado de azúcar (Miguel, 2013: 27).

Si en María Sánchez el cuerpo de la mujer se relaciona con la anatomía animal, aquí viene a vincularse con los problemas de salud, aunque tampoco faltan las ocasiones para implementar la crítica, en algunos casos dirigida contra esa visión androcéntrica que dicta las normas de belleza, como en este irónico fragmento en prosa: "Mi amigo el ruso dijo que yo no era una buena mujer. Remarcaba la erre de «eres»y de «mujer». Tú no «erres» una buena «mujerr» porque llevas las uñas mal pintadas" (Miguel, 2013: 14); para abordar la precariedad que experimenta como joven fuera del núcleo familiar: "El único lujo aquí/ es el agua caliente" (Miguel, 2013: 28); a propósito de la dificultad de crecer, de ese "miedo a no cantar más/ las penas de la última infancia" (Miguel, 2013: 30); o acerca de los entresijos de una vida en pareja que empieza y todas sus etapas "Tejer contigo/ el terror a la disputa" (Miguel, 2013: 31).

Las reivindicaciones feministas pasan por reconquistar el terreno de lo íntimo. Luna Miguel no conoce tapujos para proyectar el sexo en sus escritos, entre los que no son ajenas las menciones explícitas a partes del cuerpo entendidas como eróticas como la "vagina", el "clítoris"; o la "polla", así como las palabras asociadas al acto sexual como "semen", "mamada" o el verbo "follar"; lo que también confirma, por otra parte, su breve ensayo El dedo. Breves apuntes sobre la masturbación femenina (Capitán Swing, 2016) — cuya promoción fue motivo para censurar su cuenta de Facebook-, práctica de la que también hace gala en poemas como "Anatomía": "Aprende a lubricar tus dedos. [...] Aprende a introducirte a Cristo por el orificio nasal. ¿Cuál de los dos? El de más abajo. El de más abajo" (Miguel, 2013: 70) ${ }^{16}$.

En este poema lleno de provocación surge de nuevo la falta de autoconocimiento de la mujer sobre su propio cuerpo y sus órganos sexuales que desvelaba asimismo María Sánchez. La carencia de libertad sexual que tradicionalmente ha cargado a sus espaldas el género femenino ha entorpecido el camino de la equidad, llegando a expropiar a las mujeres de su propia fisionomía e instaurando un pudor que ha trascendido generaciones. Aquí se suma, además, la presión social que viene sufriendo la mujer ante los cambios que el paso del tiempo infunde en su físico: "Eres deforme: el pelo hinchado. La piel de una libélula. El flujo de nácar. Duro. Duro. El pecho duro. Ya no tienes dieciséis años" (Miguel, 2013: 70).

\footnotetext{
${ }^{16}$ La masturbación, esta vez en el seno de una relación, volverá a ser descrita en "Primera noche y karaoke en Shibuya", de El arrecife de las sirenas: "te lames los dedos y me los metes/ haciendo pequeños círculos indoloros [...] tu aliento a alcohol de 3.000 yenes me penetra/ haciendo pequeños círculos caemos rendidos/ al colchón [...]" (Miguel, 2017b: 53).
} 
Aunque acontecerá especialmente en su último poemario, la maternidad deviene motivo de reflexión desde La tumba del marinero, en cuyo desenlace hallamos un debate relativo a la felicidad que mueve a la voz poética a plantearse lo oportuno de traer hijos al mundo: "Comprender a los bebés que desconozco. A los que nunca he tocado. Mira qué mundo le entregas a esos bebés. Mira qué mundo les das y qué olor les das y qué sabor les das: ¿es néctar acaso?" (Miguel, 2013: 102).

La cuestión de la maternidad y el miedo a tener hijos está presente asimismo en Los estómagos, en este caso sujetos a la presencia de la enfermedad afincada en la familia y al temor a ser heredada por las generaciones venideras, lo que se transmite con mucha intensidad en versos como: “'Tendrás hijos y morirán!” (Miguel, 2015: 33), o en este fragmento de "Azor común”: “Lo sé: la enfermedad anida en nuestros espejos. // Lo entiendo: y lavaré mi sexo con lejía. Frotaré mi sexo con lejía para que mis hijos nazcan sanos”. (Miguel, 2015: 36).

También la deliberación alusiva al cuerpo pasa aquí por la enfermedad, concretamente en cuanto a la manera en que el cáncer va devastando a su madre hasta la metástasis, mientras la vOz poética se aferra a las resonancias de la niñez: "Ahí resiste su cuerpo blanquecino y caliente. Exige precisión pero no acierta. Exige luz pero no brilla. Exige peso pero sus tetas son delgadas: allí crecí” (Miguel, 2015: 33).

En este poemario, en el que, por cierto, se pasean también muchos animales, coincidimos con esta "Definición del vientre":

Todo está entre el pecho y la vagina. Todo lo

importante

está y seguirá estando [...]

De qué manera podríamos definir el vientre.

De qué manera

la caja torácica esconde otra materia gris. El

estómago

está entre el pecho y la vagina. Más lejos o más

cerca que los nervios. Más lejos o más cerca

que el amor de la mascota (Miguel, 2015: 22).

El vientre es donde se puede gestar la vida, pero también el lugar que alberga el estómago, que nos permite digerir el alimento imprescindible para vivir ${ }^{17}$. Es asimismo el espacio donde

\footnotetext{
${ }^{17}$ En lo que concierne al estómago, hay en este poemario una recurrente preocupación relativa a la alimentación, el consumo de carne y el respeto a los animales -"Creo en el amor entre especies" (Miguel, 2015: 59)-, que encontrábamos también en María Sánchez.
} 
anidan el nerviosismo e incluso los sentimientos. Nos alejamos, pues, de la reducida conexión vientre-maternidad, poniendo de relieve su función esencial, la misma que se le otorgaría a su homólogo masculino, al igual que sucedía con los senos en la lírica de María Sánchez. Al situarlo concretamente entre el pecho y la vagina, las dos partes más aunadas al erotismo femenino, Luna Miguel está restando importancia a estos últimos elementos, carentes de funciones indispensables al artefacto vital.

Pero es concretamente en su último poemario donde la autora se concentra de un modo más preciso en el cuerpo femenino, ofreciendo con naturalidad consideraciones socialmente incómodas o poco comunes en relación a la fertilidad, el aborto, los entresijos del embarazo o el sexo. En El arrecife de las sirenas, Luna Miguel nos lleva de viaje por varios rincones de la geografía como México, Roma o Japón, desde los cuales recapacita sobre la existencia después del fallecimiento de la madre, tras haberse tornado un "poeta huérfano" (Miguel, 2017b: 16), y desde una cierta obsesión por 'fecundar', como se titula la primera sección. Advertimos un "vientre deseando vida" (Miguel, 2017b: 16), un deseo asido a la superación de esa muerte dolorosa, ya que el recuerdo de la progenitora flota en estas páginas mientras el sujeto lírico se busca a sí mismo en los diferentes destinos que transita.

La voz poética se vuelve sexualmente explícita y delatora de la frustración ante un embarazo que no llega en versos como "y estuviste a punto de correrte dentro por qué no lo hiciste" (Miguel, 2017b: 15), o en el poema titulado "Google Calendar me recuerda que estoy ovulando", en el que se mezclan la incertidumbre ante una posible maternidad y la invocación de su propia infancia, como un espejo en el que se miran madre e hija:

$$
\begin{aligned}
& \text { qué difícil poner la semilla } \\
& \text { qué fácil alcanzar el placer } \\
& \text { qué miedo no darte nada } \\
& \text { qué fracaso no florecerme } \\
& \text { ni desearme }
\end{aligned}
$$$$
\text { ni amamantarme de nuevo (Miguel, 2017b: 18). }
$$

En efecto, existe toda una reflexión en torno a la maternidad y lo que esta conlleva, incluso antes de que tenga lugar, con ecos palpitantes de Sylvia Plath -cuya biografía Magia cruda (2017) prologó la autora- y las distintas posibilidades de percibir este estado conceptivo que fraguaba en los poemas de Tres mujeres (1962).

Lejos de ser un proceso bello, es aquí relatado en un primer momento con angustia, como una condición que puede ser "un capricho, un obvio remedio a la muerte o una venganza de vida" (Miguel, 2017b: 19), y que lleva a la protagonista a acuñar una fe insólita nunca antes experimentada, comparable a la del enfermo desesperado por sanar.

También hay lugar para las cicatrices, que se inscriben directamente en el cuerpo y en sus heridas, físicas y psíquicas, afiliándolas al decoro que suscita la exhibición de sus partes más 
íntimas, al que ya aludía en el primer poemario: "las cicatrices son eso que no enseño porque me da vergüenza./ como un órgano sexual”. (Miguel, 2017b: 22).

El cuerpo, como la vida, está marcado por múltiples cicatrices que nos conforman. Una de ellas se descubre en estas páginas en forma de aborto. En un esfuerzo por exteriorizar esta experiencia, Luna Miguel relata apesadumbrada el proceso que empieza con un episodio sexual ofuscado en el que confiesa "retener el esperma entre mis muslos/ hasta que cae líquido/ al frío suelo de mi sueño", y acaba con la triste imagen de "una pantalla en la que el corazón de mi hijo se detiene" (Miguel, 2017b: 33). Este rito de creación frustrado es descrito en detalle, tanto desde las consecuencias corporales: "ya llevo más de quince días sangrando" (Miguel, 2017b: 35), como anímicas, que se fusionan con las pérdidas que pesan sobre el libro: "el ángulo de todas las muertes/ que nos hicieron daño" (Miguel, 2017b: 44).

Otro aspecto reiterado relacionado con el cuerpo es la desnudez, que, si en La tumba del marinero se concertaba esencial y figuradamente con las ausencias que dejaban desabrigada a la protagonista, aquí se transforma en la condición literal -y literaria- que esta adopta para escribir en uno de sus poemas, recordando el estado original del ser humano y su versión más primaria, en la que predomina la función reproductiva, "porque desnudos es como hacemos a los bebés" (Miguel, 2017b: 35). El sexo se convierte en una especie de obsesión hasta que se obtiene el fruto deseado y se produce una nueva gestación, que es definida desde el inicio hasta el momento de dar a luz en la sección titulada 'Ulises', nombre que llevará el hijo de la autora, concebido en su viaje a Japón (Gómez Urzaiz, 2016). El proceso comporta numerosos cambios en el cuerpo de la madre y una gran inquietud, como se narra en el poema "Mamífero", que al igual que vimos en María Sánchez, asemeja al hombre con los animales en esta etapa tan instintiva:

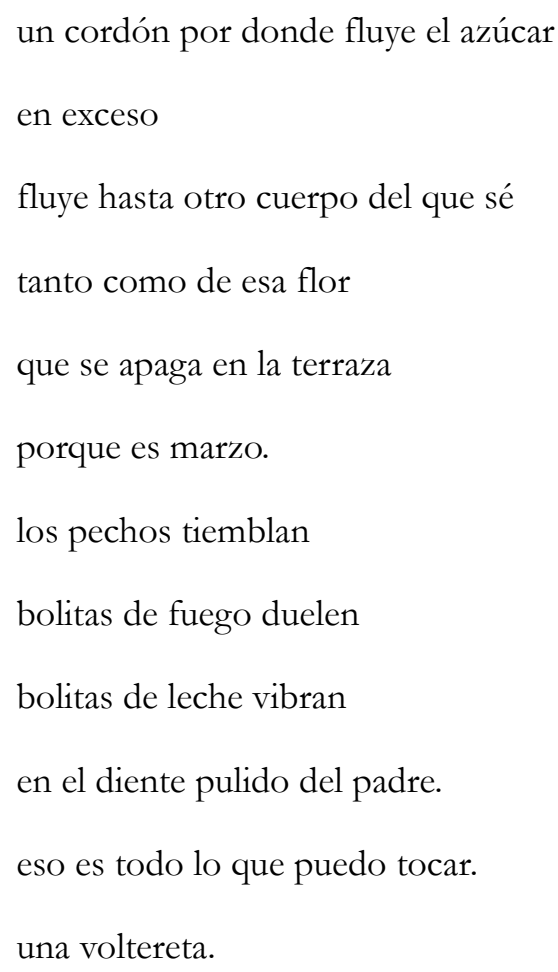


un hipo.

una contracción.

una estría en el costado (Miguel, 2017b: 67).

La inexperiencia induce al desconcierto en muchas de las etapas, como sucede en el caso de la lactancia, a la que también hace referencia en varias ocasiones. La autora pone sobre la mesa una premisa de la que se ha hablado mucho en los últimos tiempos - con respecto a la libertad de la madre de amamantar en público, maniobra que parece ofender a los retractores. Luna Miguel consigue poetizar este gesto con espontaneidad, en su caso refiriéndose a la llegada de la leche al pecho, a su materialización, logrando transmitir un proceso tangible, con el que estamos poco familiarizados, en el poema titulado "Calostro es una palabra muy fea":

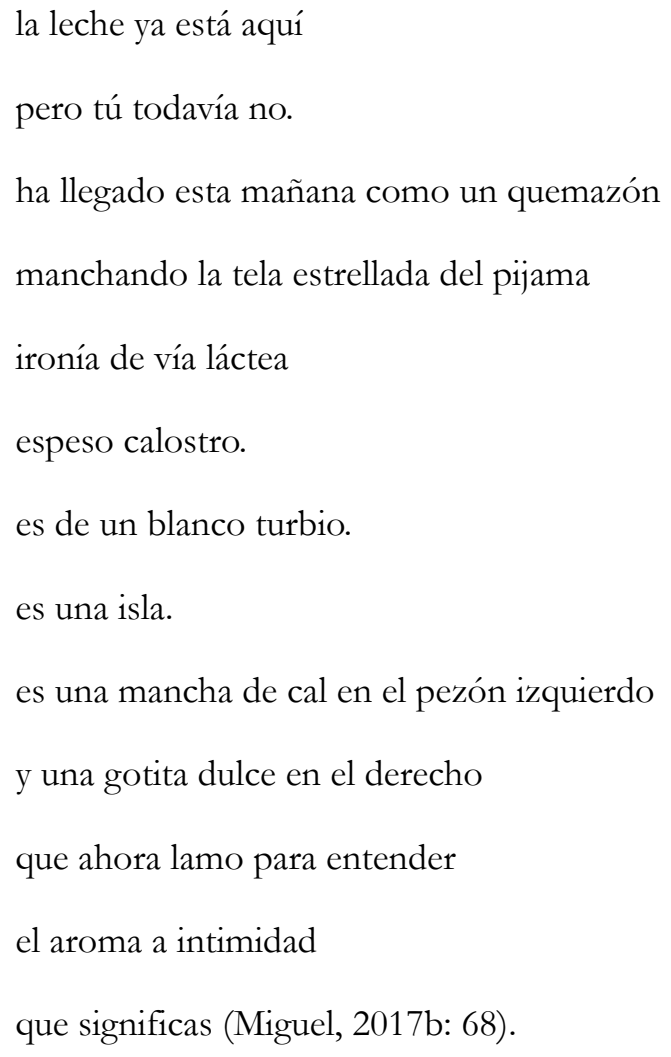

La figura del pecho se emparenta con la nueva posibilidad de alimentar, pero no se olvida de su condición placentera, de su carácter sexual: "las creíamos sagradas/ hasta que él descubrió/ cómo convertirlas en sexo/ cómo devolver el placer al alimento/ el alimento al placer [...]” (Miguel, 2017b: 73). El mundo no se detiene después del parto, la madre no descarta cuidarse a sí misma ni desatiende su relación de pareja, aunque consciente de la alteración que conlleva la llegada del nuevo miembro, como expone en el poema titulado "¿'Te habrá cambiado mucho la vida, no?": "por ejemplo las peleas con papá son en silencio/ por ejemplo si me masturbo después me lavo las manos con jabón muy fuerte” (Miguel, 2017b: 74).

El cuerpo de la progenitora se torna considerablemente perceptible, pero también el del futuro retoño, su formación y evolución de feto a individuo, las dudas en cuanto al sexo y su 
llegada a la vida, en la que también prosigue la hesitación. Asistimos al relato de una madre primeriza con sentimientos encontrados que no idealiza la maternidad, sino que hace frente a sus dificultades y miedos a través de estos versos confesionales, con ilusión unas veces, con angustia otras — “[...] a veces me arrepiento" (Miguel, 2017b: 74), desde una intimidad entrañable, pero también desde una manifiesta inseguridad compartida con otras muchas mujeres a las que aproxima su experiencia. Ese niño "que nació de un corte en el vientre" (Miguel, 2017b: 70), es $\tan$ extraño que ni siquiera se asemeja a un ser humano. Comienza un mundo de cosas nuevas y hermosas, aunque también de "ictericia, pezonera y pinza" (Miguel, 2017b: 70). La madre observa minuciosamente a su hijo, pero se ocupa asimismo de exponer los pormenores de la transformación que ella misma experimenta, tanto en su propio cuerpo, como en su disposición para vivir con los nuevos hábitos. La autora refiere también con una delicada ternura esa debilidad que se establece entre una madre y el fruto engendrado, cuando hasta las cosas que pueden ser desagradables a priori declinan en belleza, pero lejos de sublimar la experiencia hasta la perfección:

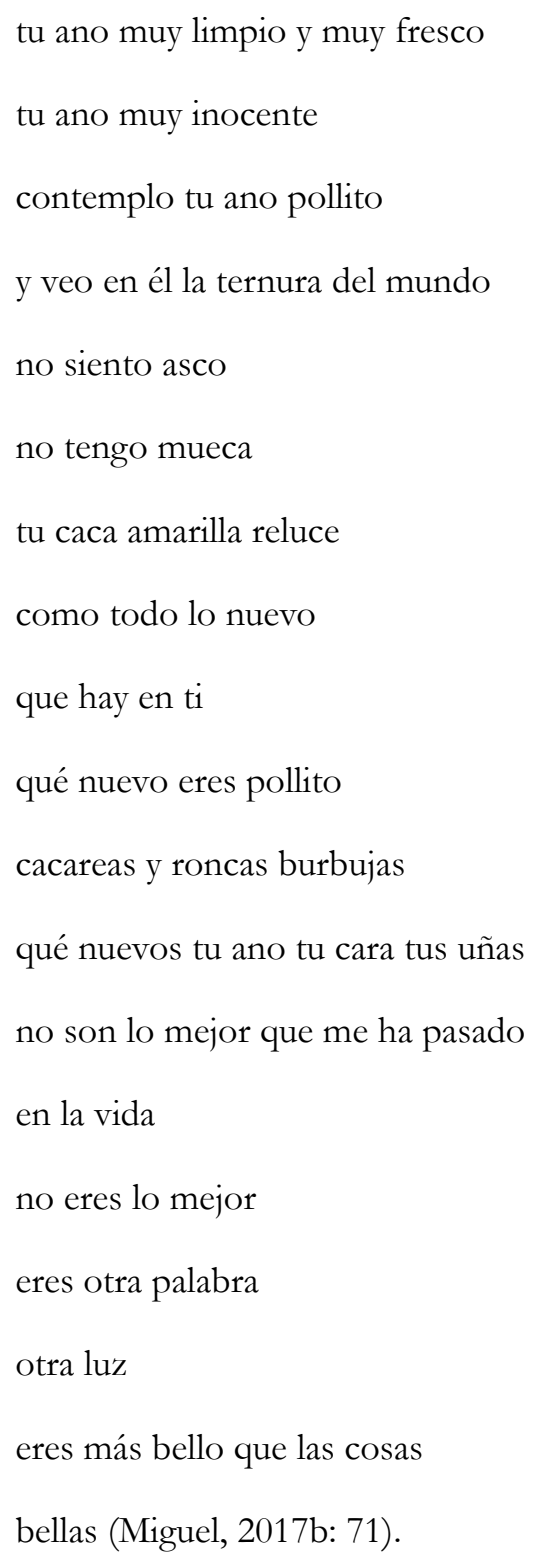


En este poemario no solo hay lugar para las vicisitudes materno-filiales. También distinguimos resquicios de crítica al patriarcado y alusión a las trabas con las que tropieza la mujer escritora. Aquel amigo ruso que dictaminaba lo que era ser una buena mujer no es el único hombre que se alza con derecho a juzgar o dar consejos en los versos de Luna Miguel. Aquí le toca el turno a un poeta que indica qué palabra es apropiada utilizar, cuál es el proceder correcto en el camino de la creación poética, aunque contradiga la voluntad de la propia autora:

Un poeta feo me dijo que no escribiera gladiolo en un poema

el poeta feo no quería gladiolos

el poeta feo repudiaba la palabra gladiolo

cuando en realidad es una palabra muy hermosa

me gusta la palabra gladiolo (Miguel, 2017b: 36).

La prepotencia del varón nos hace pensar en otro poema de la autora titulado "Poesía masculina", que fue transcrito en su blog y que forma parte de un proyecto inédito provisionalmente titulado "Un hombre". Se trata de una producción que tiene mucho en común con un dilema candente en nuestros días: los abusos sexuales que se están dando a conocer en ámbitos artísticos y que ponen de relieve un machismo que se expande a sectores que hasta ahora habían permanecido en silencio. Nos enfrentamos al testimonio del propio acosador, que acude a su posición privilegiada para procurarse favores sexuales, incluso en el seno de la pareja, y que ni siquiera necesita hablar para satisfacer su deseo:

nunca le he pedido que me coma la polla

en todo caso

he empujado levemente con el borde de mis palmas

la barricada de su omóplato

levemente

sutilmente

nunca he sido demasiado sutil

para qué voy a serlo si me llamo hombre

si con el borde de las palmas de mis manos

ya ordeno levemente

opacamente (Miguel, 2017c).

Por lo tanto, no solamente presenciamos la exploración en el cuerpo propio, sino también las agresiones ajenas que lo moldean, ya sea en el plano del estremecimiento causado 
por las punzantes pérdidas o en el de la intimidación física y verbal por parte de agentes externos. Es así como en Luna Miguel, el cuerpo se articula bajo diversas apariencias y posibilidades de acción, componiendo una reflexión profunda de la experiencia de la autora a través del mismo, a veces desgastado por el dolor, a veces receptor del placer, pero siempre tangible en las distintas vivencias que se van delineando. La poeta contribuye con su obra a reformular nociones que el androcentrismo se ha apropiado para sí en imágenes casi siempre reductoras, ajenas a una realidad que pone continuamente de relieve el apremio que insta a alterar los estereotipos de género, siempre favorables a las esferas de poder. Su lectura ayuda a adaptar nuestra mirada a las nuevas exigencias, convirtiéndose en asunto necesario a la hora de acostumbrarse a percibir el cuerpo, la sexualidad y la identidad de la mujer con la libertad e independencia que merecen ${ }^{18}$.

\section{Elvira SaStre: “[...] QUe UNA PERSONA ESTÁ hECHA DE OTRAS/ Y TÚ OCUPAS TODO MI CUERPO" (SASTRE, 2015: 97).}

La benjamina de las poetas que abordamos, nos ofrece una lírica que difiere radicalmente de las anteriores al emanar de una temática esencialmente amorosa, que bebe de los clásicos, y que consideramos atractiva por constituir una puesta en escena de los pormenores de las relaciones en un contexto homosexual. La voz poética nos adentra en el mundo de la sexualidad lésbica sin reservas, describe el amor —así como el desamor- entre dos mujeres de un modo tan desenvuelto que sorprende por su frescura, su franqueza, y la proximidad con que se acerca a un lector poco acostumbrado a encontrarse con alternativas a lo que algunos entienden como amor tradicional. Sin embargo, veremos cómo a pesar de que la autora haga inclusión de un

\footnotetext{
18 A propósito de estos dictámenes y de todo el artículo en general, es llamativa la síntesis del problema y el reclamo que suponen estas afinadas líneas de la pensadora feminista argentina Rita Segato: "Si tuviéramos que construir una alegoría gráfica, pictórica, del mundo hoy, en esta modernidad avanzada, la alegoría sería una de esas pirámides invertidas que forman los acróbatas en los circos, donde una a una se van superponiendo hileras de equilibristas hasta armar un edificio completo de gente a duras penas superpuesta, pies sobre cabezas, estrato sobre estrato, pero allá abajo, en la fundación, en la base de la pirámide, yacería, sustentando el edificio todo, un cuerpo de mujer. Muchas veces me imagino esa estructura, porque me parece ser lo único capaz de explicar por qué permanece imposible algo que a simple vista se presenta tan sencillo de realizar como retirar a la mujer de la posición de subordinación en que se encuentra, castigada, subyugada, agredida; impedir que continúe siendo violada, traficada y esclavizada por la trata, cosificada y desmembrada por el ojo del lente mediático. No sería una tarea difícil, bastarían unas pocas acciones, unas pocas medidas, intervenciones puntuales no muy complicadas. Pero por alguna razón no se puede. Se presenta imposible. Nunca hubo más leyes, nunca hubo más clases de derechos humanos para los cuerpos de seguridad, nunca hubo más literatura circulando sobre derechos de la mujer, nunca hubo más premios y reconocimientos por acciones en este campo, y sin embargo las mujeres continuamos muriendo, nuestra vulnerabilidad a la agresión letal y a la tortura hasta la muerte nunca existió de tal forma como hoy en las guerras informales contemporáneas; nuestro cuerpo nunca fue antes tan controlado o médicamente intervenido buscando una alegría obligatoria o la adaptación a un modelo coercitivo de belleza; nunca tampoco como hoy se cerró el cerco de la vigilancia sobre el aborto que, sintomáticamente, nunca antes fue un tema de tan acalorada discusión como lo es hoy, en la modernidad avanzada. Al pensar el tema desde esa perspectiva, al sospechar que su victimización cumple allí con la función de proveer el festín en que el poder se confraterniza y exhibe su soberanía, discrecionalidad y arbitrio, entendemos que algo muy importante debe seguramente depender, apoyarse, en esa destrucción constantemente renovada del cuerpo femenino, en el espectáculo de su subyugación, en su subordinación de escaparate. Algo central, esencial, fundacional para el «sistema» debe ciertamente depender de que la mujer no salga de ese lugar, de ese papel, de esa función” (Segato, 2016: 97).
} 
destinatario de igual sexo que el sujeto poético, la ejecución de los parámetros amatorios no deja de estar hermanada a patrones heterosexuales ya consabidos.

Elvira Sastre (Segovia, 1992), como las anteriores poetas, empezó a publicar poemas sueltos en blogs, revistas y redes sociales hasta que su primer poemario, 43 maneras de soltarse el pelo (2013), salió a la luz cuando contaba solo veintiún años, y su última publicación, La soledad de un cuerpo acostumbrado a la herida (2016), corrió a cargo de la reconocida editorial 'Visor'.

En esta interesante trayectoria nos topamos de nuevo con la introspección labrada a través de la escritura, con el designio de conocerse dentro del poema y desenredar los hilos que disponen una existencia en construcción: "escribo para enseñarme todo lo que desconozco de mí misma", enunciará la voz poética en el poema "Sólo conmigo. Sólo contra mí", perteneciente a Baluarte (2014), su segundo libro publicado (Sastre, 2015: 63).

La intimidad se esparce ya por su primer poemario, en el que asistimos al hallazgo paulatino e inocente del cuerpo del otro, en este caso de una mujer, dubitativo y constreñido todavía a lo supuestamente indebido, pero escrutando con tenacidad el camino del autoconocimiento entre los dos entes. El espacio examinado abarca varias partes del cuerpo que se mantienen ocultas frente a lo colectivo, como parcela de lo recóndito, de lo deshabitado por el tacto y las miradas externas que se ejercitan en un baile privado en estos versos:

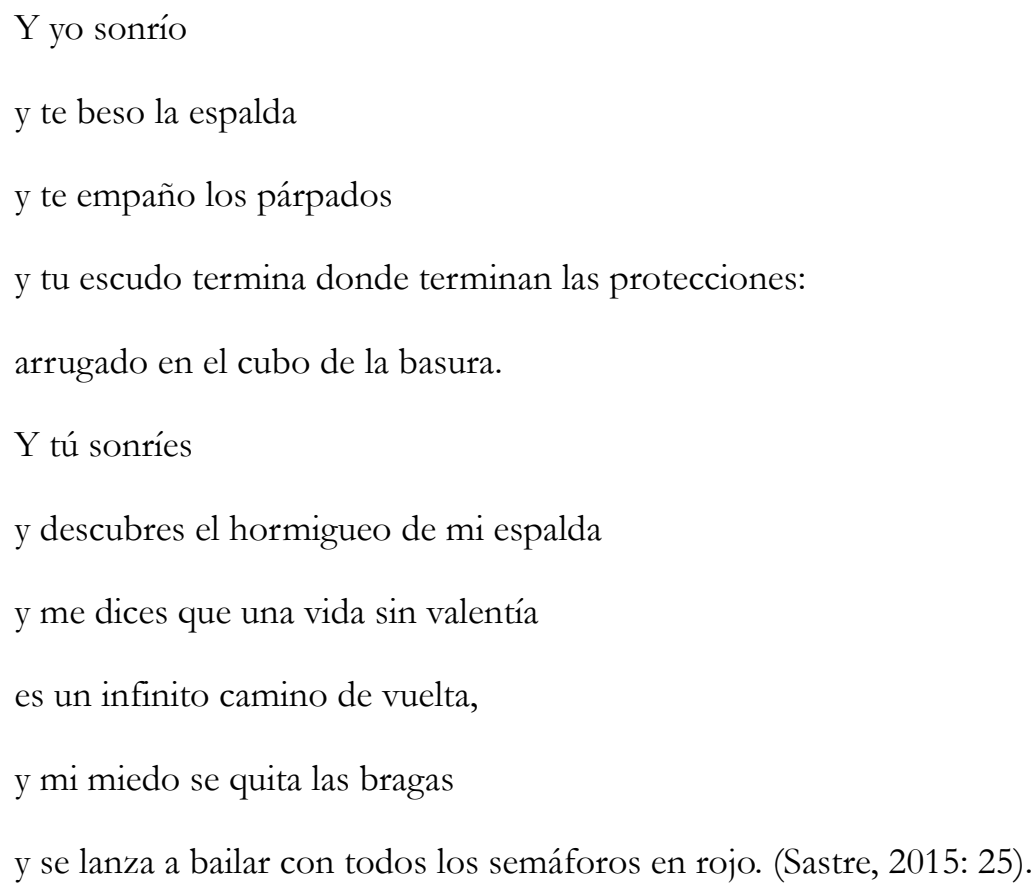

El cuerpo es siempre un lugar al que volver, un motivo constante que aparece aquí bajo diferentes formatos y repleto de oportunidades. A medida que se da a conocer, la indagación en el mismo, ya sea propio o ajeno, se transmuta en una auténtica expedición placentera que quiere ser infinita: "No quiero llegar a conocerte nunca/ para poder seguir viajando sobre tu cuerpo", confiesa el 'yo' lírico en un poema inédito (Sastre, 2015: 81). La espalda es una de las muchas imágenes que se presentan afiliadas a lo íntimo, en ocasiones rodeada por un abrazo en el que dos 
seres se entrelazan creando un mundo particular, como un refugio necesario al que se recurre cada vez que se necesita protección:

$[\ldots]$ y nos abrazamos,

como se abraza un niño al peluche

que le salva cada noche de las pesadillas,

como se abraza un cuerpo llovido y frío

a otro que le espera lleno de mantas [...] (Sastre, 2015: 27-28).

Poco a poco la timidez y la inexperiencia - "Sigo sonriendo al desnudarte/ porque todavía tiemblas ante mi torpeza" (Sastre, 2015: 82) — van abriendo paso a la desenvoltura, hasta que la protagonista se acostumbra a lo desconocido y se despliega por completo en el segundo poemario mencionado, donde nos alzamos como testigos de una hermosa y osada fogosidad que envuelve cada vez más partes de un cuerpo al que se le ha ganado terreno, de cuya conquista sistémica se está más próximo que nunca. Esas partes se encadenan gracias a múltiples símiles que los equiparan a poderosos elementos de la naturaleza o conceptos grandiosos e intangibles:

Permíteme confesarte

a ti,

ángel subido a mi pecho:

que de repente vi tus brazos salados abriéndose

como dos nubes de agua,

tu busto sinfónico inflándose como un huracán

dentro de un volcán en erupción,

tus ojos espumosos destapándose como las puertas

de mi fe ante las certezas,

tu boca llenándose de mandamientos impenetrables

como rocas milenarias,

tus piernas benévolas empapando mi suelo

de flores anacaradas,

tus dedos silentes ahogándose entre esdrújulas

arrítmicas, marítimas y selváticas,

tu voz glorificada disparando amor a mis labios resecos 
y perdidos... (Sastre, 2015: 46-47).

Tampoco Elvira Sastre demuestra impedimentos cuando se ocupa del sexo — "y puedo durar cuatro estaciones haciéndote el amor" (Sastre, 2015: 53)—, y concretamente de la masturbación, ya sea entre dos sujetos o en su estricta soledad: "Y es que resulta que a mí el crimen/ me pilló masturbándote,/ amor, o masturbándome pensando en ti” (Sastre, 2015: 52), o "Que tus dedos suaves/ vendrán infinitos a deshacerme/ los nudos" (Sastre, 2015: 96).

En la poeta segoviana, la desnudez es asimismo recurrente. Esta se supedita al deseo carnal y a la añoranza de un cuerpo perdido - "Te he vuelto a ver desnuda/ y se me han corrido los ojos de pena" (Sastre, 2015: 56)—, y se transforma asimismo en un reclamo sentimental: "mi bandera blanca es mi piel desnuda/ y hace tiempo que no paso frío" (Sastre, 2015: 59).

Escribir es quizá el único subterfugio que sirve para confesar sin pudor lo que encierra un cuerpo en ebullición, lleno de vicisitudes que exigen ser expresadas, pero también su percepción acerca del resto de cuerpos que lo conforman: "La poesía/ me permite pintarte un día/ entera del color del otoño/ hablar del movimiento de tu pelvis/ cuando atacas con violencia las aceras" (Sastre, 2015: 67). El cuerpo es el mecanismo material que garantiza la posesión, la certeza de ser dueño de uno mismo, aunque en ocasiones un cuerpo necesita de otro cuerpo para reconocerse: "sólo me valoro en otras bocas" (Sastre, 2015: 62), e incluso para existir: "Si no estás,/ este cuerpo me queda demasiado grande". Ante la pérdida, el 'yo' poético se modifica hasta devenir "un cuerpo desmembrado", "un cadáver sin sustento" (Sastre, 2015: 68), incompleto y desequilibrado. Por ello, en su último poemario publicado, de representativo título, el cuerpo ha tenido que aprender poco a poco a acostumbrarse a la herida. Nos ubicamos ante "la historia de una ruptura", como ella misma lo define (Ruíz Mantilla, 2018), y se refiere en pasado a esa experiencia que subsiste en la memoria, enumerando las posibilidades que ya nunca serán y que han dejado a la protagonista derruida, vacua:

$$
\begin{aligned}
& \text { Me llamaste isla } \\
& \text { quisiste habitarme, hacer crecer tu piel } \\
& \text { sobre mi tierra, deshacer } \\
& \text { mi invierno protegido y alumbrar } \\
& \text { el abandono elegido de la arena. } \\
& \text { Pudiste quedarte, reposar } \\
& \text { tu futuro sobre mis ruinas y hacer } \\
& \text { quizá } \\
& \text { castillos en el aliento que lancé } \\
& \text { una y otra vez sobre tu nuca (Sastre, 2016: 27). }
\end{aligned}
$$

Si los anteriores trabajos se centraban mayoritariamente en las experiencias del cuerpo protagonista y las emociones vividas a través de él y con los demás, en este último se cuenta 
cómo aprender a vivir sin ese otro cuerpo al que ya no se tiene acceso. Son sensaciones remotas, pues solo se puede revivir lo candente que persiste - "aún recuerdo cuando te recogí tras un orgasmo" (Sastre, 1026: 40)—, sabiendo que no queda nada de ese fuego "que nos prendió el cuerpo" (Sastre, 2016: 27). En esta radiografía del cuerpo ausente, el suyo propio se dedica a reconstruirlo: "Sé que te echaré de menos con los huesos [...] que recorreré con estos dedos desgastados/ la silueta de tus huellas" (Sastre, 2016: 57). Tras el abandono, la entidad corporal se siente extraña, e incluso tiende a depender del otro a pesar de ser consciente de la imposibilidad del encuentro, de manera que hasta grávidamente no existe sin él: "[...] mi peso reside en el aire que mueves en las calles/ y en las comisuras alzadas de tu boca” (Sastre, 2016: 49).

En resumidas cuentas, en Elvira Sastre los sentimientos, de amor o de dolor, siempre palpables, se liberan, se analizan y se expresan corporalmente. Como si de una performance se tratara, la voz poética va desmembrándose y confiriendo corporeidad al libro, que se impregna de materialidad. El receptor, más que leer, casi puede ver y tocar el contenido de los versos que lo confeccionan. La palabra va de la mano de cada movimiento o palpitar del cuerpo, que otorga apariencia a las sucesivas líneas, les da forma, erigiéndose en una entidad viva, capaz de crear y recrear significados. El cuerpo es prácticamente un dispositivo promocional para la escritura, una zona experimental para dar a conocer la representación lésbica del mismo, escasamente incorporada a nuestro imaginario cotidiano. No obstante, como evocamos, si bien Elvira Sastre asume el amor hacia el mismo sexo mediante el género sobrentendido en las referencias gramaticales, la homosexualidad no funciona como problemática de su poética, no se sitúa en el origen de la maniobra creativa. La cadencia romántica, la tendencia a la melancolía, la admiración y el deseo respecto al cuerpo amado, la dependencia en la que parece ser una estricta monogamia, o la idealización y el sufrimiento tras el fracaso afectivo, se siguen ajustando a la horma de la configuración amorosa heteropatriarcal. Es decir, la correspondencia íntima entre dos mujeres se sigue entendiendo aquí desde unos mismos esquemas que no son en ningún momento rebatidos. La única divergencia que se desgaja es el sexo escogido para los agentes participantes en el poema, sin que haya hendidura en la reflexión de género. Desconocemos si esta coyuntura está ligada a la asunción del beneplácito en el ámbito público por parte de la autora, o a la intención de concederle un tratamiento naturalmente abierto y sin deliberación que la expongan como una opción tan realizable como cualquier otra de las ya generalmente asumidas.

Bien es verdad que, pese a que la voluntad quede sin resolver, el hecho de hallarnos frente a la descripción pormenorizada de la estructura de dos cuerpos homosexuales y su reciprocidad, participa en la familiarización con el retrato de lo lésbico, a su integración al abanico de elecciones que nos ofrece la sexualidad y la noción de "cuerpo" en sí mismo, y a acomodarnos a una realidad plural infranqueable que contribuye, de acuerdo al razonamiento de la historiadora Mary Nash, a "la necesidad de rescatar como feminismo actuaciones, experiencias e iniciativas encaminadas al cambio social de las relaciones de género sin la implicación necesaria de su cuestionamiento abierto o global de una sociedad patriarcal" (Nash, 1994: 158). 


\section{CONCLUSIONES}

La lectura de estas poéticas revela la pertinencia de seguir redefiniendo el espacio público para naturalizar aquello que todavía se cierra al territorio de lo privado; difuminar sus fronteras otorga solidez a la viabilidad de una emancipación individual definitiva y restituye paulatinamente el lugar que necesita habitar cada entidad corporal. En la extensión de estos versos, lo personal conquista el contorno de la esfera colectiva para hacer desaparecer las limitaciones, en un intento por atacar sus confines desde una experiencia tangible de lo físico que penetra en la dimensión simbólica del lenguaje que, junto al cuerpo, se convierte en "un lugar de negociación política del mundo [...]" (Pahud, 2017: 10) ${ }^{19}$.

Nos encontramos ante un cerco contextual concreto, con sus demandas propias, que difiere de otros paisajes sociales, temporales y geográficos, pero que a su vez mantiene puntos de conexión con otras realidades que se deducen familiares. La doble condición de mujeres y literatas que encarnan las protagonistas de este trabajo supone su implicación en una tradición de reclamos que llevan años intentando ser conquistados, como la misma Luna Miguel relata en su ilustrador artículo "Cuando ser escritora es sinónimo de humillación, desigualdad y acoso sexual" (Miguel, 2017a).

Pero quizá una de las divergencias más evidentes sea la capacidad de difusión que consiguen sus obras y el alcance mayoritario de sus imágenes en el marco del impulso exponencial de las redes sociales y la órbita digital, que las ha llevado a estar significativamente presentes en entornos diversificados y conectar con un público heterogéneo. Los canales comunicativos se han visto irreversiblemente modificados con el nacimiento de la era tecnológica, habilitando cauces de expresión donde verter inquietudes en torno a todo tipo de cuestiones, así como un gran poder de convocatoria y adhesión en el plano del feminismo, que resultan igualmente idóneos para las artistas y alteran el tejido literario tradicional.

Estas mujeres están dando nuevos pasos desde su pluma para instalarse en un terreno legítimo, en el que hacer hablar a sus cuerpos, ocuparse de ellos y de sus obstáculos, acercando sus turbaciones más íntimas al lector, también al dominio de lo masculino, que avanza con ellas, como afirma de nuevo Luna Miguel en una entrevista a propósito del pasado Día Internacional de la Mujer: "Están empezando a perder el miedo a hablar de sus cuerpos gracias a que hay muchas escritoras mujeres haciéndolo. Ha sido algo liberador, no solo para nosotras sino para todos, escritores y lectores" (Marmisa, 2018).

En efecto, nada más saludable que expandir una práctica que permita construir un escenario equitativo que acabe siendo integrado en el ideario común y deshaciéndose de su carácter excepcional. Estas poetas arrojan luz a interrogantes que terminan por no ser exclusivamente suyos, que adquieren una magnitud extensible y que se vuelven parte de la solución. En palabras de Rosalía Romero Pérez: "el término autoconciencia para el feminismo es la condición que posibilita comprender y asumir la dimensión social y colectiva de los problemas personales" (Romero, 2015: 170).

19 “Comme la langue, le corps est un lieu de négociation politique du monde”. La traducción es nuestra. 
Así, ya sea desde el enfrentamiento de María Sánchez con sus orígenes y la lucha por trascenderlos y encontrar su lugar como mujer emancipada, desde la inspección en la potencialidad del cuerpo y la sexualidad femenina que va engranando Luna Miguel en sus poemarios, o desde la expresión libre del amor lésbico en Elvira Sastre, asistimos a una comunión de testimonios manifiestamente entroncados con el momento histórico en el que estamos insertos, al sentir de una andamiaje social en plena reconsideración, que se encuentra sin duda en la raíz del éxito de estas propuestas.

María, Luna y Elvira hacen de su palabra una bandera y se debaten continuamente entre la dicha y el desaliento, entre la satisfacción y la frustración, "el malestar de la felicidad" (Miguel, 2013: 65), "la belleza del sufrimiento" (Sastre, 2015: 38). Todas ellas hablan de heridas y cicatrices que perduran, heridas y cicatrices visibles o invisibles que arrastran los cuerpos; del instinto animal que les permite despojarse ocasionalmente de ataduras añadidas: “¿por qué negar al cielo que somos animales?" (Miguel, 2014: 34); de la herencia familiar recibida que las predetermina desde una infancia muy vinculante, "entre los estímulos de la destrucción y de la supervivencia" (Sánchez, 2017: 27).

Esos aparentes factores de cohesión derivan de una exploración continua en la conciencia de sí mismas, cada una de ellas desde un posicionamiento específico, que es finalmente el nexo implícito que hila sus poéticas y que procura, ya sea espontánea o intencionadamente, unos aportes a la construcción de conductas y oportunidades de afirmarse propios de su coyuntura. La congruencia actual parece indicar que no se trata tanto de rasgos generacionales o asociados a su dedicación literaria, sino entre toda una ola de ciudadanas que están pidiendo ser escuchadas y que se expresan desde sus diferentes actitudes y campos de acción para transmutar una realidad vacilante y continuamente en construcción. Como estipula Mari Luz Esteban Galarza:

[...] un movimiento social como el feminismo se va construyendo a sí mismo a través de actividades grupales que movilizan y ponen en relación los cuerpos feministas individuales, que van conformando así un cuerpo colectivo, en el sentido de desplegar, renovar y articular una emoción y una energía compartida absolutamente imbuidas de ideología (Esteban Galarza, 2011: 46-47).

Si bien no es posible justificar una intención conjunta, lo cierto es que los nombres de estas poetas suelen yuxtaponerse cuando se habla de las voces femeninas promisorias que vienen enriqueciendo el panorama poético actual y "compensando el desequilibro de género" (López, $2017)^{20}$. Estas trayectorias individuales que hemos querido hacer converger en estas páginas, favorecen gradualmente desde su escritura su justa visibilización, la confirmación de su presencia en el mundo literario y con ello, una mayor concienciación sobre la necesidad imperiosa de contar con la mujer en todas y cada una de las esferas de la vida. Juntas colaboran por la reconstrucción de una ficción identitaria femenina en un intercambio inmaterial con la comunidad, instaurando un lugar privilegiado de articulación entre lo particular y lo general, donde se alzan los poderes y se puede acelerar simbólicamente la conversión de valores, los nacientes desafíos para proteger lo

\footnotetext{
20 Algunas, incluso se han visto reunidas con motivo de eventos públicos en los que la mujer ha sido protagonista, como la charla-lectura que mantuvo el periódico El País con Luna Miguel y Elvira Sastre, entre otras, durante la celebración del Día internacional de la mujer que citamos más arriba (Marmisa, 2018).
} 
propio y lo ajeno, haciendo visibles las contradicciones presentes a la vez que se crean discursos, prácticas y subjetividades nuevas. Porque, para terminar en verso con María Sánchez, “[...] vivir en grupo facilita el avistamiento y la detección de los depredadores” (Sánchez, 2017: 36). 
BIBLIOGRAFÍA

ACKERMAN, Galia (2014). En el principio era el cuerpo. Barcelona: Calmann-Levy.

ARJONA, Daniel. “«Stop» masturbación: el dedo de Luna Miguel no cabe en Facebook”. El Confidencial (2016).

AYÉN, Xavi; MASSOT, Josep. "Las escritoras denuncian la marginación que sufren en los reconocimientos oficiales". La Vanguardia (2016).

CALDINI, Camille. "Entretien. Geneviève Fraisse, philosophe et historienne: «L'affaire Weinstein est une révolte historique et politique»”. France Télevisions (2017).

CASTRO, Rosalía (1996). Obra completa. Padrón: Fundación Rosalía de Castro.

D’ANGELO, Oriette. “María Sánchez: «El campo es una forma de resistencia»”. Digo.palabra.txt (2017).

Esteban Galarza, Mari Luz (2011). "Cuerpos y políticas feministas: el feminismo como cuerpo". Villalba Augusto, Cristina \& Álvarez LuCENA, Nacho (coords.). Cuerpos politicos y agencia. Reflexiones feministas sobre cuerpo, trabajo y colonialidad. Granada: Universidad de Granada: 45-84.

FEDERICI, Silvia (2010). Calibán y la bruja. Mujeres, cuerpo y acumulación originaria. Madrid: Traficantes de sueños.

FERNÀNDEZ LAMELAS, Eva. "Una revolución silenciosa. Memorias de activismo feminista y vecinal: de la Transición al 15M en Barcelona y su cinturón industrial”. Ankulegi 19 (2015): $25-41$

FERNÁNDEZ Rivero, Juan. “Tocar las vísceras: la poética del cuerpo en 'Cuaderno de campo’, de María Sánchez”. Ocultalit (2017).

FiguerA AyMERICH, Ángela (1986). Obras completas. Madrid: Hiperión.

GÓMEZ URZAIZ, Begoña, "El viaje de Ulises”. El País (2016).

HoOKs, Bell (2017). El feminismo es para todo el mundo. Madrid: Traficantes de sueños.

H. Riaño, Peio. “Los 21 artistas más influyentes de 2017”. El Español (2017).

LAGARDE, Marcela (1996). Género y feminismo. Desarrollo bumano y democracia. Madrid: Editorial Horas y horas.

LÓPEZ, Raquel. "La huella de la nueva poesía femenina”. Nomepierdoniuna (2017).

MARÇAL, Maria-Mercè (2004). Deshielo. Montblanc: Igitur.

MARMISA, Javier. “Día Internacional de la Mujer: La poesía por ellas”. El País (2018).

MARTíneZ, Xaime. "Cuaderno de campo: el poemario que se acerca a la belleza y a la tragedia de los mundos perdidos". Playground (2017).

MigueL, Luna (2013). La tumba del marinero. Madrid: La Bella Varsovia.

MigueL, Luna (2015). Los estómagos. Madrid: La Bella Varsovia. 
Miguel, Luna. "Cuando ser escritora es sinónimo de humillación, desigualdad y acoso sexual”. Playground (2017a).

Miguel, Luna (2017b). El arrecife de las sirenas. Madrid: La Bella Varsovia.

Miguel, Luna. "Poesía masculina”. Luna Miguel Blogspot (2017c).

Morante, José Luis (2016). Re-generación. Antología de poesía española (2000-2015). Granada: Valparaíso.

NASH, Mary. "Experiencia y aprendizaje: la formación histórica de los feminismos en España”. Historia Social 20 (1994): 151-172.

NeIRA, Nieves. "María Sánchez: «El campo es mi narrativa invisible, donde surge todo»". El progreso (2017).

PAHUD, Stéphanie. "Le corps exhibé: un texte singulier du féminisme quatrième génération", Argumentation et Analyse du Discours, 18 (2017)

Romero PÉREZ, Rosalía. "Desobediencia civil, feminismo y cuerpo". Investigaciones feministas, Vol. 6. (2015): 153-171.

Ruíz MANTILla, Jesús. “Soy poeta y vivo de esto”. El País (2018).

SALGAdO, Purificación. "L. Miguel: «Como la diabetes, la Literatura es una enfermedad crónica»”. Personas que (2013).

SÁNCHEZ, María (2017). Cuaderno de campo. Madrid: La Bella Varsovia.

SASTRE, Elvira (2016). La soledad de un cuerpo acostumbrado a la herida. Madrid: Visor.

SASTRE, Elvira (2015). Ya nadie baila. Granada: Valparaíso.

SEgato, Rita Laura (2016). La guerra contra las mujeres. Madrid: Traficantes de sueños.

Woolf, Virginia, (2018). Una habitación propia. Barcelona: Seix Barral.

Yuste, María. "Hablamos con la poeta Luna Miguel más allá de su edad o número de seguidores". Nylon (2017). 